\title{
A Foregone Conclusion? The United States, Britain and the Trident D5 Agreement
}

\author{
Suzanne Doyle \\ University of East Anglia, Norwich, UK
}

\begin{abstract}
Existing studies of the United Kingdom's purchase of Trident D5 missiles have simplified the Reagan administration's sale. Using previously classified documentation, this article highlights the potential political and financial ramifications of a sale agreement, which led to complex deliberations within the Thatcher government up until the final day of negotiations. The White House viewed the sale as a means to strengthen Western nuclear and conventional forces to counter the perceived Soviet threat. However, even within this conducive environment, US officials still drove a hard bargain with their British counterparts, in order to support US strategic interests. Indeed, the White House utilised the sale to influence British defence policy. In this way, the Trident agreement was not a foregone conclusion but rather a continuation of the friendly, but not preordained, nature of US-UK nuclear relations, that has been renegotiated, according to the varying interests of both parties, throughout its existence.
\end{abstract}

KEY WORDS: Nuclear Weapons; Thatcher; Reagan; Anglo-American; NATO

In July 2016, the House of Commons voted to replace the submarine component of Britain's Trident nuclear system. Thereafter, according to current estimates, the British government will need to take a decision in 2019 on the replacement of the Trident warhead, and then, in the following decade, a decision on procurement of new missiles to replace the current Trident D5s leased from the United States. ${ }^{1}$ Throughout all of these decisions, the United States will play a key role. The United Kingdom is technically dependent upon the United States for the supply of its nuclear delivery systems. However, despite the open debate of Trident renewal in Parliament and informed public discussion in various other forums, due to the secretive nature of nuclear diplomacy, the finer detail

CONTACT Suzanne Doyle, suzanne.doyle@uea.ac.uk

${ }^{1}$ House of Commons Library, 'Briefing Paper: Replacing the UK's Nuclear Deterrent', 8 Mar. 2016, accessed on 20 April 2016, http://researchbriefings.parliament.uk/ResearchBriefing/Summary/CBP7353\#fullreport; UK Government White Paper, 'The Future of the United Kingdom's Nuclear Deterrent', Dec. 2006, accessed on 8 June 2015, https://www.gov.uk/government/uploads/system/uploads/attachment_data/file/27378/DefenceWhite Paper2006_Cm6994.pdf. 
of US-UK negotiations over Trident replacement will likely remain shrouded in secrecy until future declassification of archival records.

Due to the recent declassification of archival material in Britain and the United States, it is now possible to provide an in-depth analysis of the US-UK negotiations over the supply of Britain's Trident D5 nuclear system over thirty years ago; the last time Britain replaced its nuclear force. Given the secrecy of US-UK negotiations on the supply of US delivery systems, such analysis is of historical and contemporary importance.

Hitherto, there has been little archival analysis of the Trident D5 negotiations. Subsequently, much of the existing literature stresses the aggressive stance of Reagan towards the Soviet Union and the friendship between Thatcher and Reagan as the underlying reason for the favourable terms that the British received on the purchase of the D5 missile. ${ }^{2}$ In recent years, there has been valuable new archival research on Britain's decision-making on the replacement of Polaris. ${ }^{3}$ However, the Trident negotiations were bilateral in nature and thus a dynamic process. As such, a national approach is limited in the conclusions it can draw. In utilising original material from the British National Archives and the Ronald Reagan Library, this article incorporates both sides of the negotiations and thus builds upon previous analyses of the deal. Within its focus upon the bilateral negotiations, the article's central theme is the role that the interests of the Reagan administration played in influencing and shaping the Trident negotiations. The second and interrelated theme is the ways in which the UK's technical dependence on the US influenced British policymaking.

Whilst nuclear decision-making is often conceived as being underpinned by the logic of deterrence, throughout the negotiations US officials were not overtly concerned with nuclear strategy or targeting. ${ }^{4}$ Whilst US officials saw the sale of Trident as a means to strengthen Western nuclear deterrence, they concurrently viewed the sale as a means

\footnotetext{
${ }^{2}$ A. Dobson, Anglo-American Relations in the Twentieth Century: of friendship, conflict and the rise and decline of superpowers (London: Routledge, 1995), 150-152; J. Dumbrell, A Special Relationship: AngloAmerican Relations from the Cold War to Iraq (Basingstoke: Palgrave Macmillan, 2006), 183; R. Aldous, Reagan \& Thatcher: The Difficult Relationship (London: Random House, 2013), 56-58; G. Smith, Reagan and Thatcher (London: Bodley Head, 1990), 68-71.

3In 2014, Kristan Stoddart published the first study of Britain's decision-making on Polaris replacement using documents from the British National Archives. See K. Stoddart, Facing Down the Soviet Union: Britain, the USA, NATO and Nuclear Weapons, 1976-1983 (Basingstoke: Palgrave Macmillan, 2014).

${ }^{4}$ This is in concurrence with the work of Francis Gavin, who questions the centrality of the logic of deterrence within US nuclear decision-making. For example see F. Gavin, Nuclear Statecraft: History and Strategy in America's Atomic Age (New York: Cornell University Press, 2012); F. Gavin, 'Strategies of Inhibition: U.S. Grand Strategy, the Nuclear Revolution, and Nonproliferation,' International Security 40/1 (2015), 9-46.
} 
to reinforce the political and conventional strength of the Western alliance. For the US, the success of the latter depended upon the negotiated terms for the supply of Trident D5. As such, the issue of Britain's conventional spending dominated negotiations.

The British government remained uncertain, until the last day of formal talks, over the possible political and financial cost of the advanced missile system due to the Reagan White House's attempts to utilise the sale as a means to influence British defence policy. An analysis of these negotiations reveals the extent to which the Thatcher government relied upon the forthcoming attitude of the US government in their efforts to replace Britain's Polaris force, as well as the influence of the White House's wider strategic, economic and political interests upon the sale itself. Due to the convergence of US-UK defence interests, the Reagan administration agreed to provide Trident D5 missiles at a substantially reduced cost. However, at the same time they utilised the sale to extract commitments from Britain on the maintenance of its conventional forces. As such, the Trident D5 agreement reinforced the North Atlantic Treaty Organisation (NATO), and thereby Reagan's vision of a US-led Western alliance that could counter the Soviet Union through both nuclear and conventional strength. Moreover, just as Reagan's hostility to social democracy shaped his foreign policy towards Latin America, it also influenced the administration's approach to the sale of Trident D5 and the British Labour Party. ${ }^{5}$

Given the secrecy of current US-UK negotiations over Trident renewal, these historical events are of particular contemporary relevance. As David Gill has recently demonstrated, historical debates have great utility for analysing present day nuclear strategy. ${ }^{6}$ In addition, the Trident D5 negotiations raise pertinent questions over the influence of the United States upon British decision-making, as well as the role that the British political elites' belief in the necessity of an independent deterrent may play in Trident renewal in spite of strong counter-arguments.

\section{The British Dilemma}

In July 1980, the Thatcher government and the Carter administration agreed the US sale of Trident C4 missiles to replace Britain's Polaris system. The British government

\footnotetext{
${ }^{5}$ See T. Carothers, In the Name of Democracy: US Policy toward Latin America in the Reagan Years (Oxford: University of California Press, 1991); P. Kengor, The Crusader: Ronald Reagan and the Fall of Communism (New York: HarperCollins Publishers, 2007). 6D.J. Gill, 'Strength in Numbers: The Labour Government and the Size of the Polaris Force,' Journal of Strategic Studies 33/6 (2010), 819-845.
} 
believed that they had secured the future of Britain's nuclear force. However, in November 1980 Ronald Reagan won the US presidential election on a platform of US strategic modernisation. Subsequently, in August 1981, the Reagan administration decided that the US would replace the Trident C4 missile with the more advanced Trident D5 missile by $1989 .{ }^{7}$ Following this decision, Washington informed London that it was prepared to sell the D5, but did not provide any reassurances that it would supply the advanced missile on the same terms as the C4. ${ }^{8}$ The US decision on the D5 was of crucial importance to Britain's effort to replace its Polaris nuclear system. Due to Britain's technical dependence on the United States for nuclear missiles, the choice to replace Polaris was largely constrained to US delivery systems, lest the British choose to pursue more economically costly options. As such, in the autumn of 1981, following Ronald Reagan's public announcement of his decision, the British government had to decide whether to proceed with Trident $\mathrm{C} 4$, and entail the risk of losing commonality with the US system, or upgrade to the D5 system and negotiate a new agreement with the US for the Polaris replacement. ${ }^{9}$

Neither option was ideal. If Britain procured the C4 whilst the United States Navy switched to Trident D5, it would entail a loss of commonality when the Americans phased the C4 out of service. In all likelihood, this would happen only a few years after British deployment of the new system. As such, if the British chose to stay with the $\mathrm{C} 4$, they risked spending huge sums to maintain the missiles. In 1967, the government of Harold Wilson opted not to purchase US Poseidon missiles but instead delayed a decision to upgrade the Polaris system by redirecting work at Aldermaston to the Super Antelope project, later named Chevaline, which would investigate improving the front-ends of the existing missiles. ${ }^{10}$ In 1973, Edward Heath, Wilson's successor, decided to improve Polaris through the Super Antelope programme. ${ }^{11}$ Both the Wilson and Heath governments' decisions to pursue the secret project were mainly due to the domestic political and

\footnotetext{
${ }^{7}$ [Kew, United Kingdom, The National Archives (hereafter TNA)] FCO 46/2751, Thomas to Gillmore, 'The Trident D-5 Decision', 25 Aug. 1981.

${ }^{8}$ TNA, PREM 19/417, Weinberger to Thatcher, 24 August 1981; Reagan asked Weinberger to send this letter to Thatcher on the President's behalf, see TNA, DEFE 24/2126, Weinberger to Nott, 25 Aug. 1981.

${ }^{9}$ Ronald Reagan, 'Remarks and a Question-and-Answer Session with Reporters on the Announcement of the United States Strategic Program,' 2 Oct. 1981, The American Presidency Project. http://www.presidency.ucsb.edu/ws/?pid=44333; TNA, PREM 19/417, Reagan to Thatcher, 1 Oct. 1981. ${ }^{10} \mathrm{~A}$. Priest, 'In American Hands: Britain, the United States and the Polaris Nuclear Project 1962-1968,' Contemporary British History 19/3 (2005), 366-367.

${ }^{11}$ H. Parr, 'The British Decision to Upgrade Polaris, 1970-4,' Contemporary European History 22/2 (2013), 253-254.
} 
financial ramifications of the public purchase of a US delivery system. ${ }^{12}$ However, by 1981 the astronomical costs of Britain's Chevaline programme had provided the British government with a stark lesson on the potential costs of losing commonality with the US. ${ }^{13}$ The recent British discovery of the need to re-motor the existing Polaris rocket motors, following test-firing failures, had made the potential costs of losing commonality even more apparent to the Thatcher government. ${ }^{14}$ The estimated costs of this remotoring was $£ 300$ million, further straining the already stretched defence budget. ${ }^{15}$

The Reagan administration's current offer of the Trident D5 system also came with drawbacks. Whilst the D5 offered better range and accuracy than the $C 4$, this more advanced system came with an increased price tag. With the D5 still in the early stages of research and development, the extent of these extra costs was unpredictable. Furthermore, the D5's capabilities were entirely disproportionate to Britain's defence requirements. ${ }^{16}$ The Trident D5 was 'not just a modernised C4... [but] a completely new missile.' ${ }^{17}$ Alongside the MX missile, the D5 was at the forefront of US ballistic missile technology. ${ }^{18}$ Subsequently, the proposed acquisition of such a costly and advanced weapon could fuel the arguments of those opposed to the replacement of Polaris on moral grounds, as well as those who feared that Trident would diminish Britain's conventional strength. Therefore, the American decision to upgrade to D5, left British ministers with a difficult dilemma over the replacement to the Polaris system.

The Reagan administration's approach to the Cold War meant that it was in its perceived interests to negate the problems the purchase of Trident D5 could cause the British Conservative government. From 1981-1983, the US adopted a highly

\footnotetext{
${ }^{12}$ K. Stoddart, 'The Wilson Government and British Responses to Anti-Ballistic Missiles 1964-1970,' Contemporary British History 23/1 (2009), 1-33; Priest 'In American Hands', 353-376; J. Baylis and K. Stoddart, 'Britain and the Chevaline Project: The Hidden Nuclear Programme, 1967-82,' Journal of Strategic Studies 26/4 (2003), 124-155; T. Robb, 'Antelope, Poseidon or a Hybrid: The upgrading of the British Strategic Nuclear Deterrent,' Journal of Strategic Studies 33/6 (2010), 797-817; K. Stoddart, 'The British Labour Government and the Development of Chevaline, 1974-79,' Cold War History10/3 (2010), 287-314; Parr, 'The British Decision', 253-274; An official history on Chevaline by Professor Matthew Jones, LSE, is forthcoming.

${ }^{13}$ See TNA, DEFE 19/275, Duff Mason Report, Dec. 1978; TNA, CAB 130/1222, 'Most Confidential Record to MISC 7 (81) 1st meeting', 24 Nov. 1981.

${ }^{14}$ TNA, PREM 19/417, Nott to Thatcher, 'UK Strategic Nuclear Force', 14 Sept. 1981.

${ }^{15}$ Hansard, vol. 32, c153w, Polaris HC debate, 16 Nov. 1982.

${ }^{16}$ See TNA, DEFE 19/275, Duff Mason Report, Dec. 1978; G. Spinardi, From Polaris to Trident: The Development of US Fleet Ballistic Missile Technology (Cambridge: Cambridge University Press, 1994), 141163.

17TNA, FCO 46/2751, Defence Department, Foreign \& Commonwealth Office, 24 Sept. 1981. 18Ibid.
} 
confrontational policy towards the Soviet Union. ${ }^{19}$ In some ways, Reagan's approach resembled President Jimmy Carter's after he had hardened his policy towards the Soviet Union following its invasion of Afghanistan. ${ }^{20}$ However, Reagan had warned about the communist threat to US security for many years, and indeed long before his predecessor's reappraisal. He believed, in contrast to many US policy-makers before him, that the Soviet Union's desire for world communism meant it could not be appeased. ${ }^{21}$ As part of this, Ronald Reagan wanted the US and its western allies to strengthen their conventional and nuclear forces to thwart this perceived Soviet threat. ${ }^{22}$ Margaret Thatcher was supportive of this confrontational approach to the Cold War. ${ }^{23}$ Although budget restraints limited the Thatcher Government's ability to strengthen the UK's armed forces, they nonetheless prioritised the replacement of its Polaris system. Reagan's concurrent belief in the need to strengthen Western forces provided the White House with an implicit rationale to support the British government's endeavours.

The Reagan administration's approach to arms control also suggested that the supply of Trident D5 to the British would be readily forthcoming, in contrast to the early Carter administration. ${ }^{24}$ In 1981, the Reagan White House viewed arms control issues as a low priority. Throughout his election campaign, Reagan said he would reject the Strategic Arms Limitation Talks (SALT) II Treaty, arguing that it only bolstered the military imbalance. Instead, he planned to restore US defences in order to negotiate from a position of strength, and then seek deep reductions in nuclear arsenals. ${ }^{25}$ Reagan believed that in the meantime US arms control policy should seek to enhance 'national

\footnotetext{
${ }^{19} \mathrm{~B}$. Fischer, The Reagan Reversal: Foreign policy and the end of the Cold War (Missouri: University of Missouri Press, 2000), 3.

${ }^{20} \mathrm{O}$. Njølstad, 'The collapse of superpower détente, 1975-1980,' in The Cambridge History of the Cold War: Volume III Endings, ed. M.P. Leffler and O.A. Westad (Cambridge: Cambridge University Press, 2010), 135155; N. Mitchell, 'The Cold War and Jimmy Carter,' in The Cambridge History of the Cold War, 66-88; S. Kaufman, Plans Unraveled: The Foreign Policy of the Carter Administration (De Kalb: Northern Illinois University Press, 2008); D.J. Sargent, A Superpower Transformed: The Remaking of Foreign Relations in the 1970s (New York: Oxford University Press, 2015), 261-295.

${ }^{21}$ Fischer, The Reagan Reversal, 18; R. Garthoff, The Great Transition: American-Soviet Relations and the End of the Cold War (Washington DC: The Brookings Institution, 1994), 8-10; C.J. Pach, Jr., 'Sticking to His Guns: Reagan and National Security,' in The Reagan Presidency: Pragmatic Conservatism and its Legacies, ed. W.E. Brownlee and H.D. Graham (Lawrence: University Press of Kansas, 2003), 87.

22Pach, 'Sticking to His Guns', 85; J.L. Gaddis, Strategies of Containment: A Critical Appraisal of American National Security Policy during the Cold War (New York: Oxford University Press, 2005), 354.

${ }^{23}$ P. Sharp, Thatcher's Diplomacy: The Revival of British Foreign Policy (London: MacMillan Press, 1997); M. Thatcher, The Downing Street Years (London: HarperCollins, 1993), 68-69.

${ }^{24}$ See S. Doyle, 'A Foregone Conclusion? The United States, Britain and the Trident missile agreements, 1977-1982' (PhD diss., University of East Anglia, 2015).

${ }^{25}$ Pach, 'Sticking to His Guns', 89; F. Fitzgerald, Way Out There in the Blue: Reagan, Star Wars and the End of the Cold War (New York: Simon \& Schuster, 2000), 111; Gaddis, Strategies of Containment, 352.
} 
security by limiting Soviet systems most threatening to the US.' ${ }^{26}$ Subsequently, from 1981-1983, the Reagan administration's approach to arms control stymied progress. Instead of SALT II, in November 1981, the administration proposed the Strategic Arms Reduction Talks (START). The purported purpose of the talks was to reduce the overall number of strategic weapons in the superpowers' arsenals. However, Reagan refused to begin negotiations until June 1982. Moreover, the administration proposed a cap on landbased warheads that would have required the Soviets to destroy more than half of their arsenal, whilst allowing the US to increase its numbers. As Moscow relied primarily on land-based missiles for its 'deterrent', reducing them by half would have weakened its position vis-à-vis the West. ${ }^{27}$ Given the administration's confrontational rhetoric and military build-up, the one-sided proposal appeared disingenuous. Understandably, the Soviets rejected the proposal, calling it a 'propaganda ploy.'28 With such an approach on arms control, the Reagan administration was unconcerned about the affect of the supply of the D5 on US-Soviet arms control efforts. Nevertheless, despite this convergence of interests, in the autumn of 1981 the Reagan administration did not offer the British any reassurance over the possible terms of supply of the D5. Indeed, US officials had previously made clear to the Thatcher government that they would expect conventional commitments in exchange for any reduction in the price of Trident. ${ }^{29}$

On 25 June 1981, the Thatcher government announced extensive cost cutting and restructuring of Britain's military forces, which would reduce the army, navy and civilian defence work force. The Thatcher government viewed these changes as a necessary reallocation to key strategic areas in light of increased costs, rather than cuts to Britain's defence spending. ${ }^{30}$ The Trident programme was one of the areas that the Thatcher government wished to fund. ${ }^{31}$ Although it was a means to raise funds for Trident, news

\footnotetext{
${ }^{26}$ [Simi Valley, United States, Ronald Reagan Library (hereafter RRL)], NSC: Meeting Files, Box 3, NSC00021 15 Sept. 1981, Allen to Reagan, 'National Security Council Meeting September 151981 - 4:00 - 5:00 PM', 14 Sept. 1981.

${ }^{27}$ B. Fischer, 'US Foreign Policy under Reagan and Bush,' in The Cambridge History of the Cold War: Volume III Endings, ed. M.P. Leffler and O.A. Westad (Cambridge: Cambridge University Press, 2010), 271; Fischer, The Reagan reversal, 27-28.

${ }^{28}$ Ibid., 2.

${ }^{29}$ See TNA, FCO 46/2751, Watkins to Gillmore, 'US/UK Defence Co-operation', 27 Aug. 1981; TNA, FCO 46/2752, Gainsborough, 'Draft Trident R\&D Levy: Background', 14 Oct. 1981.

${ }^{30} \mathrm{R}$. Vinen, 'Thatcherism and the Cold War,' in Making Thatcher's Britain, ed. B. Jackson and R. Saunders (Cambridge: Cambridge University Press, 2012), 202.

31RRL, Sven Kraemer Files, Box 90100, NATO-Countries-UK April 1981 - August 1981, London to Defense, 7 July 1981.
} 
of the British Defence Review provoked US concern. ${ }^{32}$ The White House did not view the replacement of Polaris as the only key strategic area for the UK's defence budget. Reagan officials believed that, in order to meet the global challenge of the Soviet Union, the Western alliance needed to build both strategic and conventional capabilities. In particular, Caspar Weinberger, US Secretary of Defence, thought that nuclear strength was no substitute for conventional forces in vital regions, such as the Persian Gulf.33 Indeed, Washington did not want to have to spend even more on defence because of allied withdrawals. In June 1981, Weinberger met with John Nott, UK Defence Secretary, to discuss concerns over the British Defence Review. ${ }^{34}$ In this meeting, the US Secretary of Defence suggested several ideas, including 'greater US support for the Trident programme', which could ease Britain's financial pressures, and thus limit the need for conventional cuts. ${ }^{35}$ Weinberger and Nott agreed to the establishment of a US-UK working group for detailed discussions on salient defence areas affected by budgetary restrictions. However, in the first two US-UK Defence Co-operation Working Group meetings American officials stressed that they desired defence commitments, particularly on naval deployment outside of the NATO area, in return for a reduction in the research and development (R\&D) levy for Trident. ${ }^{36}$

The R\&D levy offered the White House a subtle means to influence British defence policy. The 1963 Polaris Sales Agreement (PSA) included a five percent R\&D surcharge on the purchase price of each missile in recognition of the research and development costs the US had already incurred. The Kennedy White House decided to charge the British for R\&D in order to ensure that the sale was viewed as part of a partnership rather than a 'charitable contract', as they felt the original Skybolt deal had been, and as a means to develop greater cost-sharing within NATO.37 The levy was not set pro rata of US spending on R\&D due to concurrent awareness that the more Britain spent on its nuclear force, the less it had to spend on its conventional forces. ${ }^{38}$ However, since 1976, US

\footnotetext{
${ }^{32}$ RRL, National Security Files (NSC): Country Files, Box 20, United Kingdom Vol. 1 1/20/81 - 8/81 (4 of 6), Weinberger to Reagan, 'Meetings with John Nott on British Defense Review', 22 June 1981. ${ }^{33}$ Pach, 'Sticking to His Guns', 94.

${ }^{34}$ RRL, National Security Files (NSC): Country Files, Box 20, United Kingdom Vol. 1 1/20/81 - 8/81 (4 of 6), Weinberger to Reagan, 'Meetings with John Nott on British Defense Review', 22 June 1981.

${ }^{35}$ Ibid.

${ }^{36}$ See TNA, FCO 46/2751, Watkins to Gillmore, 'US/UK Defence Co-operation', 27 Aug. 1981; TNA, FCO 46/2752, Gainsborough, 'Draft Trident R\&D Levy: Background', 14 Oct. 1981.

${ }^{37}$ A. Priest, Kennedy, Johnson and NATO: Britain, America and the Dynamics of the Alliance (Oxon: Routledge, 2006), 55-56.

38Ibid., 56.
} 
regulations stipulated that the government had to charge a R\&D levy on a pro rata basis. The President could only approve a reduction in the R\&D charge if he believed this was in the wider interests of the US. The conduct of US officials in the US/UK Defence Cooperation Working Group meetings strongly suggested that the Reagan administration was prepared to use this leverage over the R\&D levy to extract certain conventional commitments from the British. As a UK official commented after the meetings, 'There is no doubt that what the Americans are engaged in is an attempt to introduce alterations into the defence programme... in exchange for financial savings in the Trident programme... and to ensure a continued RN [Royal Navy] presence in areas important to the US.' 39

In spite of a convergence in defence interests and early indications that Washington welcomed British procurement of the D5 rather than C4, a new Trident agreement favourable to the British government was far from a foregone conclusion. Indeed, David Gillmore, head of the Defence Department at the British Foreign Office, sent a stark warning to a number of British officials in September 1981: 'As I think you agree, we clearly need to be extremely cautious lest at the end of the day we find the Americans making some pretty excessive demands of us as a quid pro quo.'40 Undoubtedly, when British minsters met to decide whether to proceed with the C4 or upgrade to the D5, imprecision and uncertainty clouded their decision-making.

\section{MISC 7}

On 24 November 1981, a British Cabinet committee made up of a select group of ministers, titled MISC 7 (Miscellaneous 7), met to make a decision on whether the successor to Polaris should be the Trident D5 rather than C4. This group had been established in May 1979 to decide upon the replacement of Polaris as well as related nuclear issues. The group consisted of Margaret Thatcher and the four Department Ministers concerned with the decision: the Foreign Secretary, the Defence Secretary, the Home Secretary, and the Chancellor of the Exchequer. ${ }^{41}$ As had occurred repeatedly in

\footnotetext{
39TNA, FCO 46/2751, Watkins to Gillmore, 'US/UK Defence Co-operation', 27 Aug. 1981.

${ }^{40}$ TNA, FCO 46/2751, Gillmore to Stewart, 'Defence Collaborations with the Americans: Trident et al', 18 Sept. 1981.

${ }^{41}$ For details on the setting up of this Cabinet Committee, see TNA, PREM 19/14, Hunt to Thatcher, 'Nuclear Matters', 14 May 1979.
} 
the history of Britain's nuclear programme, decision-making on the replacement to Polaris was limited to a very small circle. ${ }^{42}$

When this select group met in November 1981, ministers still did not know the terms of supply for D5, whether the US would offer them a reduction in its price, or the commitments that the US would expect from Britain in return. Notwithstanding, John Nott remained seemingly impervious to any doubt about the necessity of D5 acquisition. To begin the meeting, Nott expressed his belief that Reagan's decision to cease deployment of Trident C4 as early as 1998 'meant that it would no longer be sensible for the United Kingdom to acquire the C4, since it would become unique to the United Kingdom almost from the outset of its deployment on British boats in 1994.'43 Instead, Nott recommended that Britain procure a Trident D5 four-boat force. As Nott's memorandum to MISC 7 on the D5 proposal acknowledged, until the British undertook 'detailed discussions... with the US authorities' it would be 'impossible to predict with precise accuracy what a UK D5 system would cost.' ${ }^{44}$ However, Nott remained optimistic. Due to the Reagan administration's desire to help the British with pressures on their defence budget, Nott believed that the Americans would offer a reduced price for the D5, and maybe even a R\&D levy less than the five percent charge for the Polaris and Trident C4 sales agreements. ${ }^{45}$

Other British officials deemed Nott's optimistic appraisal too simplistic, believing that it overlooked many significant difficulties. As Cabinet Secretary Robert Armstrong highlighted to Thatcher, Nott's proposal glossed over the 'very great uncertainties in the costings of a D5 force. ${ }^{46}$ Even if the British were able to secure reductions from the administration, they still faced the risk of a huge escalation in eventual costs due to the unforeseen difficulties that invariably emerge during defence development projects. The estimates of the C4 programme had already increased in real terms by 20 percent since MISC 7 had decided to purchase the missile. ${ }^{47}$ These increases had occurred in spite of the C4 missile being at an advanced stage of development. With the D5 system still in its

\footnotetext{
${ }^{42}$ See J. Baylis and K. Stoddart, The British Nuclear Experience: The Role of Beliefs, Culture, and Identity (Oxford: Oxford University Press, 2015).

43TNA, CAB 130/1222, 'Most Confidential Record to MISC 7 (81) 1st meeting', 24 Nov. 1981.

${ }^{44}$ TNA, CAB 130/1160,'Cabinet Nuclear Defence Policy, United Kingdom Strategic Deterrent Memorandum by the Secretary of State for Defence', 17 Nov. 1981.

${ }^{45}$ Ibid.

46TNA, PREM 19/694, Armstrong to Thatcher, 'The United Kingdom Strategic Deterrent MISC 7 (81) 1', 23 Nov. 1981.

47TNA, FCO 46/2751, Weston to Acland, 'C4/D5', 2 Oct. 1981.
} 
early stages of development, the ultimate costs remained unknown, but there was clearly a real potential for cost escalation to go far beyond the Ministry of Defence's (MOD) current estimates. ${ }^{48}$ Given the increase in the costs of Trident to increasingly formidable proportions,' MOD financial staff, and even the Chiefs of Staff, were 'increasingly restive about the potential impact of Trident for other parts of the defence programme.'49

The increased costs of the D5 system compared to the C4 could also be likely to have problematic political ramifications for the Thatcher government. At this moment in time, the cost of Britain's nuclear programme was particularly contentious after Francis Pym, Nott's predecessor, revealed the existence of the secret Chevaline programme with an estimated cost of about $£ 1000$ million to Parliament on 24 January 1980.50 Amongst the British public, their government's agreement to base Intermediate-Range Nuclear Force (INF) missiles in the country was also extremely controversial. ${ }^{51}$ The increased capability and costs of D5 would likely embolden the opposition Labour Party and a growing anti-nuclear movement to aggressively campaign against an expensive modernisation of Britain's strategic nuclear forces, beyond the country's need, while the welfare state faced severe cuts. According to opinion polls a majority of the country, ranging from 48 percent to 61 percent, opposed INF deployment. ${ }^{52}$

Much of the opposition to the government's nuclear policy focused on the decision to station US cruise missiles in the UK rather than the acquisition of Trident C4. The public believed cruise missiles to be 'a new and substantial addition to Western nuclear capability'53; whilst they viewed Trident as a 'continuation of the existing British fourboat deterrent force.'54 However, with the greater capability of the D5, opposition to it amongst the British public was more likely. Moreover, if the Thatcher government did not secure a substantially reduced price for the D5, it could be difficult for them to present the upgrade as a necessary cost-saving choice. Instead, opponents to Trident could more forcefully argue that the government took the decision in order to increase the country's nuclear capability. If the British public believed the acquisition of D5 was an increase in

\footnotetext{
${ }^{48}$ TNA, PREM 19/694, Armstrong to Thatcher, 'The United Kingdom Strategic Deterrent MISC 7 (81) 1', 23 Nov. 1981.

${ }^{49}$ TNA, FCO 46/2751, Weston to Acland, 'C4/D5', 2 Oct. 1981.

${ }^{50}$ Hansard, vol.977, cols. 681-683, Mr Francis Pym, 24 Jan. 1980.

${ }^{51}$ See K. Stoddart, 'Creating the "Seamless Robe of Deterrence",' in The Euromissile Crisis and the End of the Cold War, ed. L. Nuti et al. (Washington DC: Woodrow Wilson Center Press, 2015), 176-195.

${ }^{52}$ See M.E. Guasconi, 'Public Opinion and the Euromissile Crisis', in The Euromissile Crisis, 273.

53TNA, FCO 46/2750, Gillmore to Acland, 'Trident Public Attitudes', 5 Feb. 1981.

${ }^{54}$ Ibid.
} 
nuclear capability rather than the 'replacement' of Polaris, this could fuel opposition to Trident and cruise missile deployment, as well as boost support for Labour's disarmament policies. ${ }^{55} \mathrm{~A}$ decision to upgrade to D5 could also increase opposition from those on the traditional right, nominally supportive of Britain's nuclear programme, who might argue that the increased costs of D5 would 'cause further detriment to the UK's conventional forces.'56

Proceeding with the $\mathrm{C} 4$ could also create political problems. US-UK renegotiation of the C4 agreement was now necessary because of the cost increases of the system, due to Reagan's strategic modernisation decision and exchange rate movements. ${ }^{57}$ The subsequent public announcement would draw attention to the system's higher price than originally stated. Moreover, the inevitable chattering of defence analysts could make the tricky public presentation of a new $\mathrm{C} 4$ deal more difficult by highlighting that costs were likely to increase further due to the loss of commonality with the US. Once again, all this could contribute to anti-Trident sentiment in sections of the British public.

Subsequently, all ministers present at the MISC 7 meeting, bar John Nott, were hesitant to make a decision on the successor to Polaris due to fears about the financial and political costs of both options. Francis Pym, now Lord President of the Council, 'worried that the proposed switch from C4 to the even more powerful D5 missile would adversely affect both public opinion today and the attitude of whatever government emerges from the next elections.'58 Lord Carrington, Foreign and Commonwealth Secretary, 'shared these worries, and was also concerned at the greater difficulty of keeping a D5 force out of future arms control negotiations. ${ }^{59}$ As such, in a policy clearly driven by the possible political ramifications of opting for an advanced system rather than financial concerns, Carrington favoured staying with $\mathrm{C} 4$ for the moment, and switching to the D5 later. These political ramifications also concerned Geoffrey Howe, Chancellor of the Exchequer, but his greater fear was the potential costs of losing commonality with the US. He therefore supported adoption of the D5 but preferred only 12 missile tubes per boat, even though it only offered a small saving. Thatcher though was

\footnotetext{
55TNA, FCO 46/2750, From Gillmore, 'Trident', 16 July 1981.

${ }^{56}$ Ibid.

57TNA, CAB 130/1160, 'Cabinet Nuclear Defence Policy, United Kingdom Strategic Deterrent Memorandum by the Secretary of State for Defence', 17 Nov. 1981.

${ }^{58}$ TNA, PREM 19/694, Armstrong to Thatcher, 'The United Kingdom Strategic Deterrent MISC 7 (81)', 11 Jan. 1982.

59 Ibid.
} 
concerned about the increased financial outlay of the D5 and feared that the 'costs of D5 were uncertain and likely to escalate well beyond the present estimate.' 60 Finally, and most dramatically, William Whitelaw, Home Secretary, 'accepted the case for D5 against the other alternatives, but felt that the choice with which Ministers were faced raised a still more fundamental question: whether the United Kingdom could afford to continue to maintain an independent strategic nuclear deterrent.'61

After extensive discussion about the problematic choice British ministers faced, the meeting ran out of time, and with no clear solution to the predicament, the discussion finished on a cliff-hanger: 'Despite the enormous difficulties involved it might become necessary to consider the possibility of Britain ceasing to be a nuclear power.' ${ }^{2}$ With no time to consider this dramatic statement, Thatcher wrapped up the meeting: due to 'insufficient time on this occasion for Ministers to take any decision', and she suggested that, 'A whole day should be devoted to collective ministerial consideration.'63 The uncertainty about the costs of the D5 system had impeded MISC 7's decision-making. This hesitation by MISC 7 over the future of Britain's nuclear programme, and indeed its future as a nuclear power, was remarkable. In May 1979, when MISC 7 first met to discuss the successor to Polaris there had been no discussion on whether the system should be replaced. ${ }^{64}$ This reflected the British elites' belief in the necessity of an independent deterrent since the end of the Second World War. ${ }^{65}$ Subsequently, the doubts of MISC 7 in 1981 demonstrate the severe political and financial ramifications they foresaw if they chose either of their two options.

Ironically, the British notion of an independent deterrent rested upon a high level of transatlantic technical dependence. In order to solve their dilemma over the future of Britain's nuclear programme, the British government needed the Americans to offer a very favourable price for the D5. A substantial reduction in price could help mitigate the associated political risks MISC 7 ministers foresaw in opting for the expensive system. British ministers needed Nott's hope - namely that they could persuade the Americans to offer better terms than that of the Trident C4 agreement - to become reality. For the moment, with a lack of any assurance from the US about the price of D5, British ministers

\footnotetext{
${ }^{60}$ Ibid.

${ }^{61}$ Ibid.

${ }^{62} \mathrm{Ibid}$; the records of the meeting do not detail who made this contribution.

${ }^{63}$ Ibid.

64TNA, CAB 130/1109, MISC 7(79) 1st Meeting, 'Cabinet Nuclear Defence Policy', 24 May 1979.

${ }^{65}$ See Baylis and Stoddart, The British Nuclear Experience.
} 
remained uncertain about the costs, thus delaying the Polaris replacement programme. Underpinning the problem was Britain's dependency on the US for the provision of its nuclear capability: they had to take or leave whatever the United States offered, and this uncertainty could evidently complicate decision-making.

\section{Inherent Belief}

The Reagan administration held a deep interest in stemming the domestic financial and political ramifications that the D5 upgrade could cause the Thatcher government. As discussed, Reagan believed that the restoration of a 'satisfactory military balance' with the Soviet Union was an imperative. ${ }^{66}$ Moreover, the White House was deeply concerned about the political situation in Britain and the possibility that the Labour Party could defeat the Conservatives in the next general election with disastrous consequences for the US's strategic interests.

Margaret Thatcher had been elected in 1979 promising a renewal of Britain's beleaguered economy through a programme of economic liberalisation. However, by the time of Reagan's election, many had judged the economic policies of the Thatcher government to be a disaster. Unemployment had soared to ten percent, workers in the public sector were threatening to strike, and inflationary problems persisted. ${ }^{67} \mathrm{By}$ January 1981, Thatcher's political popularity had been somewhat eroded. With the next election due by May 1984, political commentators predicted that, if there was no reversal in the economic downturn by late 1982 or 1983, Thatcher could find herself ousted as leader of the Conservative Party. ${ }^{68}$ Thatcher's precarious political situation inevitably affected her government's ability to offer its usual unwavering support for US policy. Subsequently, in July 1981, John Louis, US ambassador to Britain, warned that the administration, 'Must prepare... for a period in which we shall have difficulty counting fully on our usually staunchest ally, even as Thatcher will be clutching our coattails.' 69

In addition, Thatcher's political woes worried Washington because it meant that a Labour victory or a Labour-led coalition in the next election looked increasingly likely; a

\footnotetext{
${ }^{66}$ RRL, NSC: Meeting Files, Box 3, NSC00021 15 Sept 1981, Allen to Reagan, 'National Security Council Meeting September 151981 - 4:00 - 5:00 PM', 14 Sept. 1981.

${ }^{67 R R L}$, Edwin Meese Files, Box CF219, United Kingdom - General (February 1901-July 1981), Allen to Reagan, 'Your meeting with Prime Minister Thatcher', 24 Feb. 1981.

${ }^{68}$ Aldous, Reagan \& Thatcher, 36.

${ }^{69}$ RRL, NSC: Country Files, Box 20, United Kingdom Vol.1 1/20/81 - 8/31/81 (4 of 6), Louis to Haig, 'Britain Drifts', 31 July 1981.
} 
result that would not be conducive to the administration's interests. Following its 1979 electoral defeat, Labour became embroiled in a bitter internal struggle over policies and control of the party itself. ${ }^{70}$ These developments had serious ramifications for the direction of Labour's defence policies. Many within the party, especially on the left, had strong reservations about the purchase of Trident, opposed US cruise missiles based in Britain, and favoured cuts in defence spending. ${ }^{71}$ With many on the right of the Labour Party now defecting to the Social Democratic Party - recently set-up by four former Labour Cabinet members dubbed the 'Gang of Four' - and the 'radical' left in ascendance, it seemed likely that a Labour government would adopt defence policies that were antithetical to Washington's aims. ${ }^{72}$ As Alexander Haig, US Secretary of State, told Reagan in February 1981, 'The policies being expounded by the [Labour] left, which is ascendant, would seriously detract from the UK's role in NATO. ${ }^{73}$ The chances of the Labour Party securing a parliamentary majority with such an ideological programme were doubtful; such policies would be 'hard for some in the party to swallow, let alone the wider public. ${ }^{74}$ However, even as a minority government, the Labour Party presented a real threat to Reagan's foreign policy interests and were 'capable of touching off a European slide down the anti-nuclear chute. ${ }^{75}$ Nevertheless, despite the convergence of strategic and political interests, Reagan officials did not offer the Conservative government any firm reassurance over the price of Trident D5 ahead of the next MISC 7 meeting. ${ }^{76}$

On 12 January 1982, MISC 7 met again to decide on the successor to Polaris. ${ }^{77}$ Despite continued uncertainty over the D5's terms of sale, Armstrong briefed Thatcher that he did not think ministers would decide to give up Britain's nuclear weapons: 'The political

\footnotetext{
${ }^{70}$ See G. Stewart, Bang! A History of Britain in the 1980s (London: Atlantic Books, 2013), 114.

${ }^{71}$ RRL, NSC: Country Files, Box 20, United Kingdom Vol.1 1/20/81 - 8/31/81 (6 of 6), Allen to Bush, 'Your Meeting with the Earl of Cromer', 18 Feb. 1981.

${ }^{72}$ See Stewart, Bang!, 114.

${ }^{73}$ RRL, NSC: VIP Visits, Box 91434, Haig to Reagan, Briefing Book Re Visit of British Prime Minister Thatcher February 25 - 28 1981, 'Visit of Prime Minister Thatcher', Feb. 1981.

${ }^{74}$ RRL, NSC: Country Files, Box 20, United Kingdom Vol.1 1/20/81 - 8/31/81 (4 of 6), Louis to Haig, 'Britain Drifts', 31 July 1981.

75 Ibid.

${ }^{76}$ See TNA, FCO 46/2752, Gillmore to Acland, 'Trident', 7 Dec. 1981; TNA, FCO 46/2752, Hastie-Smith to Wade-Gery, 'The Polaris Successor', 10 Dec. 1981; TNA, DEFE 24/2123, Hastie-Smith to PS/S of S, 'Trident Costs', 10 Dec. 1981; TNA, FCO 46/2752, Cooper to Armstrong, 'Polaris Succession', 18 Dec. 1981; TNA, DEFE 24/2123, Weston to Legge, 'The Polaris Successor', 7 Jan. 1982.

${ }^{77}$ The full record of this meeting is currently classified.
} 
as well as the military implications of coming out are so tremendous that your colleagues are likely to conclude that we should stay in.'78

Armstrong was right. The British elites' belief in the necessity of a bomb with a 'Union Jack flying on top of it', again won out. ${ }^{79}$ Once the formal MISC 7 discussion began, there was a consensus that Britain should continue to maintain an 'independent' nuclear deterrent. ${ }^{80}$ Ministers then agreed that the Trident D5 should be the successor to Polaris, due to the 'lessons of the Chevaline project.' 81 However, many of the MISC 7 ministers were still concerned about the potential costs of the D5. As such, they decided that its procurement should be 'subject to three provisos': that the British should partake in negotiations with the US to 'determine the broad terms on which the new system could be procured'; then Cabinet would take a final decision; with the choice between a four or three-boat force 'left open for the time being.' ${ }^{2} 2$ This final consideration highlighted that the ministers believed it was 'a matter for concern that the likely cost of the Trident project had already risen sharply in real terms since its inception in 1980 and that the price might well rise further because of American decisions over which Britain would have no control.'83 As such, despite the financial and political constraints, the British government was reluctant to consider any security alternatives. However, as the three provisos made clear, the attitude of the US government would be crucial in Britain's endeavour to maintain its nuclear programme.

\section{First Round of Negotiations}

As they planned for the Trident D5 negotiations, the MOD was optimistic that the British government could secure a reduced price for Trident D5, even hoping that they 'may be able to achieve an even better deal' than the already 'advantageous' Polaris Sales Agreement. ${ }^{84}$ Their optimism arose from indications emanating from the US Executive branch that they wished for the United Kingdom to remain 'in the strategic deterrent

\footnotetext{
78TNA, PREM 19/694, Armstrong to Thatcher, 'The United Kingdom Strategic Deterrent MISC 7 (81)', 11 Jan. 1982.

${ }^{79}$ Ernest Bevin quoted in P. Hennessy, Cabinets and the Bomb (Oxford: Oxford University Press, 2007), 7; Bevin is believed to have made this remark in a meeting of the Attlee government on whether to build a British atomic bomb. This mind-set has pervaded UK decision-making since, see Hennessy, Cabinets and the Bomb; Baylis and Stoddart, The British Nuclear Experience.

${ }^{80}$ TNA, CAB 130/1182, 'Most Confidential Record to MISC 7 (82) 1st Meeting', 12 Jan. 1982.

${ }^{81}$ Ibid.

82TNA, PREM 19/695, Armstrong to Thatcher, 3 Mar. 1982.

83TNA, CAB 130/1182, 'Most Confidential Record to MISC 7 (82) 1st Meeting', 12 Jan. 1982.

84TNA, DEFE 24/2123, 'Trident Negotiating Strategy: Modalities and Aims', 5 Jan. 1982.
} 
business', although they were concerned that this should not lead to reduction in Britain's conventional forces. ${ }^{85}$ However, as US officials had indicated in US-UK Defence Cooperation meetings, although seemingly overlooked by the MOD, the administration would not reduce their calculations for the R\&D levy from a pro rata basis without securing British commitments in return. Indeed, the Reagan negotiators meticulously planned their strategy from the outset, seeking to derive certain British conventional commitments. On 6 February 1982, Alexander Haig and Frank Carlucci, US Deputy Secretary of Defence, wrote to inform the President of their intended negotiation strategy. US officials would seek a reciprocal deal, where, in return for providing the British with a cut-price missile system, they would ask their British counterparts to make commitments in geostrategic areas of concern. ${ }^{86}$ Ergo, the Reagan administration's conception of Western strategic interests, in particular Britain's conventional force contribution, was omnipresent in their negotiating strategy.

The R\&D levy was the main area of contention. Primarily, the Reagan team intended to offer an arrangement similar to the C4 agreement, where the US would forego 25 percent of the pro rata R\&D levy, receive 25 percent in currency, and the remainder in offsets. Haig and Carlucci told Reagan that, "The effect of this would be to approximately double both what the UK will pay for R\&D, and what we will forgive.'87 Thus, the Reagan team planned to utilise British technical dependence to extract a series of quid pro quos, or 'offsets', in exchange for reducing British costs. The 'offsets' that the US negotiators sought would:

Fall in two important areas in which the British are cutting forces and we would otherwise have to take up the slack: Maintaining surface naval forces in the North Atlantic, and peacetime presence in the Indian Ocean. If the British agree to do more than they had planned in these two areas, it will save the U.S. Government money and bolster Western defenses. ${ }^{88}$

The negotiators' strategy demonstrates a clear effort to reduce the price of the D5 system not only to ensure Britain's continuation as a nuclear power but also to derive military commitments in other significant strategic areas. Reagan officials, in a manner similar to various US governments before them, would take a hard-nosed approach to the US-UK

\footnotetext{
${ }^{85}$ Ibid.

${ }^{86}$ RRL, NSC: Country Files, Box 20, UK (01/25/1982 - 02/11/1982 [Too late to file], Haig and Carlucci to Reagan, 'Discussions with the British Concerning Purchase of the Trident D-5', 6 Feb. 1982. ${ }^{87}$ Ibid. 88Ibid.
} 
partnership in order to manoeuvre Britain's defence strategy in line with their own strategic vision to counter the Soviet Union. ${ }^{89}$

On 8-9 February 1982, US and UK negotiators held the first round of Trident D5 talks. Reflective of their administration's concern not to increase anti-nuclear sentiment in Britain, US negotiators were, immediately, forthcoming on the British request for 'offsets'. British arms manufacturers had voiced significant dissatisfaction in response to the C4 agreement due to the resultant UK defence expenditure in the United States. British manufacturers had also expressed fears that the purchase of Trident could lead to a downturn in conventional arms sales. ${ }^{90}$ The UK government feared that the purchase of Trident D5 could augment these criticisms within its domestic arms industry due to the increased cost of the system and a higher proportion of UK military expenditure destined for the United States. ${ }^{91}$ As such, British officials wished to secure US agreement that if they purchased D5, UK 'firms should be given a fair crack of the whip as regards subcontracts from within the whole United States Trident programme.' 92 US officials were immediately 'receptive' to this idea. ${ }^{93}$ US negotiators were also forthcoming on two of the surcharges Britain was liable to pay. On the issue of overheads, the Americans said that they could waive the minimum charge, which they estimated to be $\$ 106$ million at 1982 prices. On the facilities charge, the US negotiators said they were 'Prepared to contemplate waiving the facilities charge, which they put at $\$ 51$ million.' The British viewed these concessions as 'satisfactory.' 94

However, as Robert Wade-Gery, lead negotiator on the British side, reported to Downing Street, the US thinking on the third surcharge, R\&D, was, 'less forthcoming than we [the British] had hoped.'95 The US officials told their British counterparts, that they started from their legal obligation to calculate the levy on a pro rata basis. Calculated at

\footnotetext{
${ }^{89}$ See B. Bernstein, 'The Uneasy Alliance: Roosevelt, Churchill and the Atomic Bomb, 1940-1945,' The Western Political Quarterly 29/2 (1976), 202-320; Priest, Kennedy, Johnson and NATO, 44-46; T. Robb, A strained partnership? US-UK relations in the era of détente, 1969-77 (Manchester: Manchester University Press, 2013), 73-127; J. Colman, A 'Special Relationship'? Harold Wilson, Lyndon B. Johnson and AngloAmerican relations 'at the summit', 1964-68 (Manchester: Manchester University Press, 2004), 75-99. ${ }^{90}$ TNA, PREM 19/694, Armstrong to Thatcher, 'The United Kingdom Strategic Deterrent MISC 7 (81)', 11 Jan. 1982.

${ }^{91}$ Ibid.

92TNA, PREM 19/694, Wade-Gery to Coles, 'Trident', 12 Feb. 1982.

${ }^{93}$ Ibid.

${ }^{94}$ Ibid.

95Ibid
} 
1981 prices, this would amount to $\$ 685$ million. The Reagan team regarded approximately half that amount as offset by costs incurred by the British from their agreement during the $\mathrm{C} 4$ negotiations to pay operational costs for Rapier air defence systems on US bases in the UK. In 1980, after prolonged negotiations, US and UK officials came to an agreement that Britain would pay a five percent R\&D surcharge on its purchase of Trident C4 missiles and provide personnel for the Rapier defences, instead of payment of R\&D on a pro rata basis. ${ }^{96}$ This British commitment to provide personnel still stood. ${ }^{97}$ However, the Reagan administration now argued that the increased costs of the D5 meant that this deal still left $\$ 342$ million of the pro rata R\&D levy unpaid. The Americans said they would be willing to waive $\$ 120$ million, with the British paying $\$ 222$ million. On hearing this offer, British officials:

Made clear that this basis for R\&D calculations would be wholly unacceptable in London. Under the deal struck publicly in July 1980, we undertook to pay their Rapier manning costs; and we were abiding by that. In return, they undertook to fix the Trident R\&D levy not at a pro rata level but on a 5 per cent basis (as with Polaris). ${ }^{98}$

Discussions on the R\&D levy dominated the second day of negotiation, and by the day's end, there were 'outlines of a possible settlement.'99 Subsequently, Wade-Gery reported to London that he believed that the US could be persuaded to levy a five percent surcharge on the lines agreed for Polaris and C4. However, US negotiators indicated that such a reduction would necessitate conventional commitments, due to the need to consider Congressional reaction; the administration would have to seek Congressional approval for any Trident agreement not charged on a pro rata basis. Therefore, if the administration offered the British a reduction on the R\&D levy, 'their basic approach to Congress' would need to be that money the British were 'not forced to pay for R\&D will be money available for... [their] conventional defence effort.'100 Kristan Stoddart subsequently emphasises that this need to appease congress was why the R\&D levy was the 'big sticking point.'101

\footnotetext{
${ }^{96} \mathrm{Ibid}$; Atlanta, United States, Jimmy Carter Library, NLC-17-89-5-25-4, David Aaron to Ambassador Brewster, 15 Jul. 1980.

${ }^{97}$ RRL, Dennis Blair Files, RAC Box 5, Trident II D-5 1980 - 1982 (8 OF 11), 'Contingency Q's and A's on Press Announcement of British Purchase of Trident II Missile', no date.

${ }^{98}$ TNA, PREM 19/694, Wade-Gery to Coles, 'Trident', 12 Feb. 1982.

${ }^{99}$ Ibid.

100Ibid.

101Stoddart, Facing Down the Soviet Union, 192.
} 
However, whilst US negotiators stressed to British officials that these 'quids' were to appease Congress, material from the US archives suggests that this was not the whole truth. The Reagan White House also sought these 'quids' in order to gain, at least some, assistance with their own areas of interest. As previously discussed, when Haig and Carlucci informed Reagan of their planned strategy they told the President that they wished for offsets in 'important areas' where, otherwise, the US would 'have to take up the slack.'102 Subsequently, after the first round of talks, the US negotiators reported to Reagan that they believed their relatively tough approach meant that the British would now consider the quid pro quos that the US desired:

We offered the British an arrangement for the purchase of the missiles similar to that agreed two years ago for the TRIDENT (C-4) missile. Predictably, they told us the price we offered was higher than they wished to pay. However, they agreed to propose to us additional offsets (i.e., increases in their own defense posture in areas where we would otherwise have to assume responsibility ourselves) which could make up at least some of the difference. ${ }^{103}$

In pushing for these offsets, US negotiators took advantage of British vulnerability in the negotiations, as they had 'no real option except to go for D5.'104 Although the US government held a significant interest in maintaining Britain's nuclear status, it still sought to secure the greatest possible assistance in conventional areas. In spite of a clear convergence of interests, a formal alliance, and a long-standing 'special relationship', the US would still seek to derive the greatest possible benefit from the negotiations, which it viewed as a key part of any final agreement. Haig and Carlucci informed Reagan that they expected the US and UK negotiators to hammer out a reciprocal deal through compromise: 'We do not anticipate that we will be able to complete the negotiations at next week's session. We will make our first offer, the British will make theirs, followed by some clarifying discussions.'105 As such, the Reagan team planned to push the British on the R\&D levy as much as possible, in order to extract reasonable commitments from them. Subsequently, US officials were happy with the first round of negotiations. They were

\footnotetext{
${ }^{102 R R L, ~ N S C: ~ C o u n t r y ~ F i l e s, ~ B o x ~ 20, ~ U K ~(01 / 25 / 1982 ~-~ 02 / 11 / 1982 ~[T o o ~ l a t e ~ t o ~ f i l e], ~ H a i g ~ a n d ~ C a r l u c c i ~ t o ~}$ Reagan, 'Discussions with the British Concerning Purchase of the Trident D-5', 6 Feb. 1982.

103RRL, NSC: Country Files, UK (01/25/1982 - 02/11/1982 [Too late to file], Stoessel and Carlucci to Reagan, 'Negotiations with the United Kingdom on Possible Purchase of Trident D-5 Missile', 11 Feb. 1982. 104TNA, PREM 19/694, Wade-Gery to Coles, 'Trident', 12 Feb. 1982.

105RRL, NSC: Country Files, Box 20, UK (01/25/1982 - 02/11/1982 [Too late to file], Haig and Carlucci to Reagan, 'Discussions with the British Concerning Purchase of the Trident D-5', 6 Feb. 1982.
} 
'optimistic' that in the next round, two weeks away, 'that we [the US] can bridge the differences between us.'106

In the interim, the MOD began 'considering urgently what limited adjustments to the conventional defence programme' the British could offer to secure reductions on the R\&D levy. ${ }^{107}$ The British needed to be resourceful in finding room for manoeuvre, although as Wade-Gery commented: 'They would need to be compatible with British interests; and of course self-balancing, since our available resources are already fully committed.'108 In the next round of talks, the British planned to present a list of these possible adjustments and to clarify that these changes were dependent on US assistance with the Trident surcharges. The British would use this approach to 'confirm waiver of the D-5 facilities charge; to accept that consideration of the level of R and D levy should start from the basis of a 5 per cent levy... to move downwards from there; and to end up with a fixed rather than a percentage figure.'109 The British expected to succeed in at least the first two of these aims, and if the Americans were unwilling or unable to give the final two, the British would limit the extent of their conventional adjustments. Such a strategy, Robert Wade-Gery believed, would enable the British 'To establish the real limits of what they think they can get through Congress.'110

\section{Second Round of Negotiations}

The second round of negotiations took place on 24-5 February 1982. By the end of the first day, the two sides had agreed everything except the elusive R\&D figure. During the course of the day, US negotiators were again, in most areas, inclined to be helpful and negate any political problems that a Trident D5 deal could cause the Thatcher government. Throughout discussions on surcharges, US officials were conscious of the need to give the British a presentable deal that could provoke as little political trouble as possible. On the overheads charge, which, for legal reasons, had to remain a percentage on the same basis as in the Polaris and C4 agreements, the Americans were 'content to follow precedent and not mention this in the published exchanges.' ${ }^{\prime 11}$ Once again, the US

\footnotetext{
106RRL, NSC: Country Files, UK (01/25/1982 - 02/11/1982 [Too late to file], Stoessel and Carlucci to Reagan, 'Negotiations with the United Kingdom on Possible Purchase of Trident D-5 Missile', 11 Feb. 1982. 107TNA, PREM 19/694, Wade-Gery to Coles, 'Trident', 12 Feb. 1982.

108Ibid.

${ }^{109}$ Ibid.

110Ibid; TNA, PREM 19/694, To Wade-Gery, 'Trident', 15 Feb. 1982.

111TNA, PREM 19/694, Wade-Gery to Nott, 25 Feb. 1982.
} 
and UK government would not reveal the full price of Britain's nuclear programme to the public. US officials also confirmed the waiver of the facilities charge. Moreover, they agreed that the R\&D levy would be a fixed sum rather than a sliding percentage. ${ }^{112}$ This vital concession would shield the British from potential cost escalation, with the US absorbing all cost increases. This would greatly assist with the public presentation of the new Trident agreement, and would help ensure the future viability of Britain's nuclear and conventional forces by minimising the risk of escalation in costs.

The reductions given by the Reagan administration on these surcharges demonstrated its clear support for Britain's nuclear and conventional forces, as well as an attempt to suppress domestic opposition in Britain to the deal. Nevertheless, the US negotiators continued to play hardball over the extent of the fixed $R \& D$ levy. In response to the British list of possible adjustments to their defence dilemmas, US officials expressed their dissatisfaction; they 'rightly perceived' that most of these 'additional' deployments were, 'no more than we [the British] could have been assumed to be planning to do anyway.'113 US negotiators then began to press 'strongly for some additional commitments in areas that would respond to current congressional preoccupations.'114 With the British seemingly outmanoeuvred, the Americans now laid out their desire for Britain to retain HMS Invincible and delay its military departure from Belize.

As Haig and Carlucci had informed Reagan before negotiations began, US officials wished to utilise the Trident sale to secure British commitments in geostrategic areas of concern, where otherwise the US 'would... have to take up the slack.'115 The US request for Britain to retain the aircraft carrier HMS Invincible reflected the administration's concerns about reductions in the United Kingdom's surface strength. As previously discussed, the Reagan administration thought that nuclear strength was no substitute for conventional forces in vital regions, such as the Persian Gulf, and that a build-up in strategic and conventional capabilities was necessary to counter perceived Soviet aggression. Subsequently, alongside their strategic modernisation, the Reagan administration planned to increase the navy's surface strength by approximately 30

\footnotetext{
112Ibid.

113Ibid.

114Ibid.

115RRL, NSC: Country Files, Box 20, UK (01/25/1982 - 02/11/1982 [Too late to file], Haig and Carlucci to Reagan, 'Discussions with the British Concerning Purchase of the Trident D-5', 6 Feb. 1982.
} 
percent. ${ }^{116}$ The benefits of this investment in the US navy would obviously be negated if the British cut their surface vessels, and the US had to fill the void; at this time, Britain contributed 70 percent of NATO's total surface fleet in the Eastern Atlantic. ${ }^{117}$ As discussed, Weinberger had spoken to Nott about US concerns over Britain's proposed cuts in surface vessels in August. ${ }^{118}$ By requesting the retention of HMS Invincible, the administration sought to use the Trident negotiations as a means to influence British policy in this area.

Similar geostrategic concerns directed the US negotiators' request that Britain retain all, or at least some, of their existing combat forces in Belize for a further five years. ${ }^{119}$ As part of the Thatcher government's efforts to end the financial burden of its remaining colonies, they had decided to grant Belize independence by the end of 1981 and at the same time withdraw all combat forces. ${ }^{120}$ Given Reagan's fears over the 'threat' of communism spreading throughout this part of South America, the White House disliked the British plans. ${ }^{121}$ The UK government had decided to withdraw in spite of Guatemala's claim to Belize. As such, Reagan officials feared that 'failure to settle the dispute now could lead to tensions between Guatemala and Belize, invite Cuban intervention and contribute to regional destabilisation.'122 In addition, Washington feared British withdrawal would hinder US efforts to suppress the perceived communist threat in El Salvador and Nicaragua, and stem contagion across Latin America. ${ }^{123}$ Subsequently, the administration sought to utilise the Trident sale as a means to ensure Britain's support in its ideological crusades in the Caribbean.

Understandably, British officials pushed back over these US attempts to influence UK defence policy. In response to the US request to retain Invincible, Robert Wade-Gery told the US officials that they expected the Australian government to announce their plans

\footnotetext{
116Pach, 'Sticking to His Guns', 94.

${ }^{117}$ A. Dorman, 'John Nott and the Royal Navy: The 1981 Defence Review Revisited,' Contemporary British History 15/2 (2010), 109.

118TNA, DEFE 24/2126, Weinberger to Nott, 25 Aug. 1981.

${ }^{119}$ TNA, PREM 19/694, Wade-Gery to Nott, 25 Feb. 1982.

${ }^{120}$ RRL, NSC: VIP Visits, Box 91434, Briefing Book Re: Visit of British Prime Minister Thatcher 02/25/1981 - 02/28/1981 92 of 2, Department of State Briefing Paper, 'UK NATO initiative', 17 Feb. 1981; RRL, Dennis Blair Files, RAC Box 5, Trident II D-5: 02/24/1982 Meeting with UK (1 of 3), 'UK Presence in Belize', 28 Feb. 1982.

121See Carothers, In the Name of Democracy; Kengor, The Crusader, 190-199.

${ }^{122}$ RRL, NSC: VIP Visits, Box 91434, Briefing Book Re: Visit of British Prime Minister Thatcher 02/25/1981 - 02/28/1981 (2 of 3), Bremer to Allen, 'Briefing Materials for the Visit of UK Prime Minister Thatcher', 25 Feb. 1981.

123S. Randall and G. Mount, The Caribbean Basin: an International History (London: Routledge, 1998$), 145$.
} 
to purchase the aircraft carrier the next day; there was 'no way' the British 'could now dishonour that offer.'124 The Americans 'regretfully accepted this.' ${ }^{125}$ Wade-Gery then revealed the possibility of a reprieval for the amphibious assault ships HMS Fearless and HMS Intrepid. Due to the valuable contribution of these landing crafts to NATO capability, US officials replied 'that this was the sort of thing they were looking for.'126

Wade-Gery gave the request on Belize short shrift, telling the US team "They should not... be under any mis-apprehension about our room for manoeuvre. A decision to station British combat forces for a prolonged period in a third world country would be a major departure in policy. I saw little chance of this being acceptable.'127 However, in his attempts to reach a compromise, Wade-Gery raised 'two less far-reaching possibilities.' ${ }^{28}$ The first was the expansion of the training programme that the British planned to provide to the Belize defence forces after the withdrawal of their combat forces. The second was a short extension, by a matter of a few months, in the length of time that British combat forces would remain in Belize. Unknown to the US officials, the British were already considering this second possibility. ${ }^{129}$ These suggestions produced a mixed response from the Americans; Robert McFarlane, Deputy National Security Advisor, replied that there might be 'promise' in the first option, but 'he gave no sign' that the second option would be of interest. US negotiators then, 'Pressed for an assurance that a regular British naval presence (e.g. one frigate) would be maintained in the Caribbean for the next five years.' In response, Wade-Gery, explained, 'That ship deployments are not normally planned in such detail so far ahead, but undertook to have the point considered as sympathetically as possible.'130

With no firm agreement on additional British deployments, the first day of the second round of negotiations ended with the final amount of the R\&D levy still unresolved. The issue would 'be hammered out in hard bargaining' the next day in light of Britain's final position on deployment. As such, after the day's discussions Wade-Gery sent an urgent telegraph to John Nott: 'In order to negotiate the lowest possible R\&D

\footnotetext{
124TNA, PREM 19/694, Wade-Gery to Nott, 25 Feb. 1982.

125Ibid.

126Ibid; Transcript of interview with Robert Wade-Gery, interview conducted by M. McBain, 13 Feb. 2000, British Diplomatic Oral History Programme, 91-92.

https://www.chu.cam.ac.uk/media/uploads/files/Wade-Gery.pdf.

127TNA, PREM 19/694, Wade-Gery to Nott, 25 Feb. 1982.

128Ibid.

${ }^{129}$ See TNA, DEFE 25/416, Jackling, 'Belize', 5 Mar. 1982.

130TNA, PREM 19/694, Wade-Gery to Nott, 25 Feb. 1982.
} 
figure tomorrow,' he needed to say 'as much as possible' in response to the specific requests made by the US officials. ${ }^{131}$ Wade-Gery subsequently asked John Nott if he could acquiesce to the desired US procedure on retention of Fearless and Intrepid, and if they could offer any private reassurances about how long they would retain them. He also enquired if there was anything they could offer the Americans on Belize that could 'be at least dressed up as an addition to current plans,' and the likely level of British naval presence in the Caribbean over the next five years. ${ }^{132}$ Wade-Gery acknowledged the flurry of activity that his telegram would provoke, but he believed a well-considered response was essential in securing a favourable deal. He stated, 'I well realize how difficult this will be and that short-notice consultation between Ministers may be needed... but anything that can be done while the iron is hot here will clearly be reflected in the deal we strike.'133

The following day, the two sides reached an agreement. The final deal was extremely favourable to the British, more so than the Trident C4 agreement. ${ }^{134}$ Britain would have to pay an overheads charge on the same percentage basis as the C4 agreement, something Wade-Gery acknowledged 'was practically unavoidable under US law.'135 However, the US would use part of this payment to set up a project liaison office that would advise British companies on how to tender for contracts. The administration waived the facilities charge, estimated at \$51 million, which was part of the C4 deal. US officials were also 'reasonably forthcoming' in response to British concerns about offsets. ${ }^{136}$ In addition to 'helpful language' in the main exchange letters, the US negotiators also offered a further side letter from Caspar Weinberger that, whilst not for publication, 'would not be confidential and could be freely drawn on in public e.g. in briefing British industrialists.'137 The two documents would make it clear that competitive British firms were eligible for sub-contracts across the breadth of the Trident programme. ${ }^{138}$ Therefore, this deal would negate the arguments of some potential

\footnotetext{
131 Ibid

132Ibid.

133Ibid.

${ }^{134}$ See TNA, DEFE 25/325, Henderson to Muskie, 30 Sept. 1980; TNA, DEFE 25/325, Christopher to Henderson, 30 Sept. 1980.

135TNA, PREM 19/694, Wade-Gery to Coles, 'Trident', 26 Feb. 1982.

136Ibid.

137Ibid.

138TNA, CAB 130/1182, 'Cabinet Nuclear Defence Policy, United Kingdom Strategic Deterrent Memorandum by the Secretary of State for Defence', 2 March 1982.
} 
opponents to Trident D5 who would argue that the system was too costly and would take valuable jobs away from British manufacturing. Moreover, with the possibility of lucrative contracts for British industry, the American offer made the deal much harder for any future Labour government to cancel.

The Reagan administration also agreed to Britain paying a fixed R\&D levy equivalent to \$116 million in fiscal 1982 dollars. This fixed amount insulated Britain from any escalation in the development costs of the D5. Moreover, the sum of \$116 million was a very generous concession from the administration. The charge was limited as though the British had stayed with the C4 and the original 1980 five percent formula had been applied. Wade-Gery subsequently thought these concessions were 'a significant improvement on the terms of the C4 agreement.'139

In the end, the British received this deal without many significant concessions on their part. On Belize, British negotiators, by describing their training plans in more detail, 'were able to avoid offering specific commitments.'140 The 'lever' that secured the concession on the R\&D levy was the decision to reprieve the naval assault ships Fearless and Intrepid, as well as the offer of a private letter from Nott to Weinberger, that administration officials could show to members of Congress. This letter would clarify the British 'intention of retaining the ships until the end of the decade and deploying them at intervals outside the NATO area.' ${ }^{141}$ British officials did not tell their US counterparts that they had already taken the decision to retain these vessels on other grounds. ${ }^{142}$

\section{Conclusion}

British negotiators were adept at using their limited resources - alongside the Reagan administration's concerns about their defence budget and the political instability of the Thatcher government - to secure this favourable deal. The British believed that Thatcher's personal relationship with the President was central to securing the US concessions. ${ }^{143}$ Yet the skill of British negotiators, or the Thatcher-Reagan relationship,

\footnotetext{
139TNA, PREM 19/694, Wade-Gery to Coles, 'Trident', 26 Feb. 1982.

${ }^{140} \mathrm{Ibid} ;$ Due to an increase in bellicose statements from Guatemala during the Falkland's crisis, as well as continued pressure from the US and Belize governments, the Thatcher government retained a substantial force in Belize throughout the 1980s, see TNA, DEFE 25/417, Franklin, 'Belize', 14 June 1982; A.J. Payne, 'The Belize Triangle: Relations with Britain, Guatemala and the United States,' Journal of Interamerican Studies and World Affairs 32/1 (1990), 119-135.

141TNA, PREM 19/694, Wade-Gery to Coles, 'Trident', 26 Feb. 1982.

142Ibid.

1435ee TNA, PREM 19/695, Armstrong to Thatcher, 3 Mar. 1982.
} 
does not fully explain the eventual deal. The US officials were also clearly good negotiators, and they had a clear strategy from the outset to secure a series of 'quids' from the British in the administration's areas of concern. Whether or not the British planned to retain Fearless and Intrepid, that the UK did so meant the White House largely achieved its aims. However, given their concurrent concern with building the conventional and nuclear forces of the 'West', as well as its fear of the growth of the anti-nuclear left in Britain and the Labour Party, the administration was never going to extort the Thatcher government in exchange for reductions. Moreover, the Americans secured concessions that, whilst not financially positive, were politically priceless.

The Thatcher government received an extremely favourable deal because of the convergence of US-UK interests. The deal demonstrated the financial price the Reagan administration was willing to pay for the political and military support of a Conservative Britain. The US government once again demonstrated its party political preferences. ${ }^{144}$ The deal was an inducement from the administration to bolster Britain's nuclear and conventional forces, secure the long-term future of these forces, and attempt to limit the commitment's effect on Britain's wider economic situation, thus stemming one aspect of the left's criticism of the deal. As Richard Perle, a senior official at the Pentagon, later remarked, the Reagan White House believed that the Trident D5 agreement was 'one more arrow in the quiver.'145 However, they wanted this 'quiver' to take a certain form. As such, at the same time as wishing to strike a favourable deal with the British, the Americans viewed the negotiations as an opportunity to get as much assistance as possible in their particular areas of concern. Ergo, Washington employed the US-UK nuclear relationship as a tool to secure the wider defence interests of the US and the Western alliance. Moreover, the Reagan administration utilised the relationship as a means to further its ideological aim to counter the perceived threat of the Soviet Union and a vocal left in Europe. As such, due to the convergence of US-UK interests, and despite the financial and political pressures to the contrary, with the assistance of the Reagan administration Britain remained a nuclear power. In this way, the Trident D5 agreement was not a foregone conclusion, which owed its completion to long-standing nuclear cooperation or the reductive logic of 'deterrence' in the Cold War era. Instead, the

\footnotetext{
${ }^{144}$ See A. Dobson, 'Labour or Conservative: Does it Matter in Anglo-American Relations?' Contemporary History 25/4 (1990), 387-407.

${ }^{145}$ C. Moore, Margaret Thatcher: The Authorized Biography (London: Allen Lane, 2013), 573.
} 
agreement was a continuation of the close but not preordained nature of the US-UK nuclear relationship, one that has been renegotiated, according to the varying political, strategic and economic interests of both parties continually over its existence. ${ }^{146}$

The previously opaque story of the Trident D5 negotiations contained within this article makes an important contribution to current debates on Trident renewal. It demonstrates that there is an entrenched belief amongst the British political elite that an 'independent deterrent' is necessary for Britain's security. Accordingly, owing to Britain's inferiority in nuclear R\&D, this creates a dependency on the US to supply the system. Combined, these two aspects of British nuclear policy led to a far greater US influence over British defence policy through the Trident D5 agreement than has previously been acknowledged.

\section{Acknowledgements}

I am grateful for the comments of Matthew Jones, Leopoldo Nuti, David Milne, Kaeten Mistry, Chris Jones and the anonymous referees on earlier drafts of this article.

\section{Notes on contributor}

Suzanne Doyle is a Postdoctoral Fellow in International Relations at the University of East Anglia. She recently completed her $\mathrm{PhD}$ thesis on the Trident missile agreements. Her research interests include US-UK relations, US and British foreign policy, and nuclear history.

\section{Bibliography}

Aldous, R., Reagan \& Thatcher: The Difficult Relationship (London: Random House, 2013).

Baylis, J., 'Exchanging Nuclear Secrets: Laying the Foundations of the Anglo-American Nuclear Relationship,' Diplomatic History 25/1 (2001), 33-61.

Baylis, J., and K. Stoddart, 'Britain and the Chevaline Project: The Hidden Nuclear Programme, 1967-82,' Journal of Strategic Studies 26/4 (2003), 124-155.

Baylis, J., and K. Stoddart, The British Nuclear Experience: The Role of Beliefs, Culture, and Identity (Oxford: Oxford University Press, 2015).

Bernstein, B., 'The Uneasy Alliance: Roosevelt, Churchill and the Atomic Bomb, 1940-1945,' The Western Political Quarterly29/2 (1976), 202-320.

\footnotetext{
${ }^{146}$ See J. Baylis, 'Exchanging Nuclear Secrets: Laying the Foundations of the Anglo-American Nuclear Relationship,' Diplomatic History25/1 (2001), 34; Priest, Kennedy, Johnson and NATO, 4-5; Dobson, AngloAmerican Relations, 124-164.
} 
Carothers, T., In the Name of Democracy: US Policy toward Latin America in the Reagan Years (Berkeley: University of California Press, 1991).

Colman, J., A 'Special Relationship'? Harold Wilson, Lyndon B. Johnson and AngloAmerican relations 'at the summit', 1964-68(Manchester: Manchester University Press, 2004).

Dobson, A., 'Labour or Conservative: Does it Matter in Anglo-American Relations?' Contemporary History 25/4 (1990), 387-407.

Dobson, A., Anglo-American Relations in the Twentieth Century: Of friendship, conflict and the rise and decline of superpowers (London: Routledge, 1995).

Dorman, A., 'John Nott and the Royal Navy: The 1981 Defence Review Revisited,' Contemporary British History 15/2 (2010), 98-120.

Dumbrell, J., A Special Relationship: Anglo-American Relations from the Cold War to Iraq (Basingstoke: Palgrave Macmillan, 2006).

Fitzgerald, F., Way Out There in the Blue: Reagan, Star Wars and the End of the Cold War (New York: Simon \& Schuster, 2000).

Fischer, B., The Reagan Reversal: Foreign policy and the end of the Cold War (Missouri: University of Missouri Press, 2000).

Fischer, B., 'US Foreign Policy under Reagan and Bush,' in The Cambridge History of the Cold War: Volume III Endings, ed. M.P. Leffler and O.A. Westad, 267-288 (Cambridge: Cambridge University Press, 2010).

Gaddis, J.L., Strategies of Containment: A Critical Appraisal of American National Security Policy during the Cold War (New York: Oxford University Press, 2005).

Garthoff, R., The Great Transition: American-Soviet Relations and the End of the Cold War (Washington DC: The Brookings Institution, 1994).

Gavin, F., Nuclear Statecraft: History and Strategy in America's Atomic Age (New York: Cornell University Press, 2012).

Gavin, F., 'Strategies of Inhibition: U.S. Grand Strategy, the Nuclear Revolution, and Nonproliferation,' International Security 40/1 (2015), 9-46.

Gill, D.J., 'Strength in Numbers: The Labour Government and the Size of the Polaris Force,' Journal of Strategic Studies 33/6 (2010), 819-845.

Guasconi, M.E., 'Public Opinion and the Euromissile Crisis,' in The Euromissile Crisis and the End of the Cold War, ed. L. Nuti, F. Bozo, M. Rey and B. Rother, 271-290 (Washington: Woodrow Wilson Center Press, 2015).

Hennessy, P., Cabinets and the Bomb (Oxford: Oxford University Press, 2007).

Kaufman, S., Plans Unraveled: The Foreign Policy of the Carter Administration (De Kalb: Northern Illinois University Press, 2008).

Kengor, P., The Crusader: Ronald Reagan and the Fall of Communism (New York: HarperCollins Publishers, 2007).

Mitchell, N., 'The Cold War and Jimmy Carter,' in The Cambridge History of the Cold War: Volume III Endings, ed. M.P. Leffler and O.A. Westad, 66-88 (Cambridge: Cambridge University Press, 2010).

Moore, C., Margaret Thatcher: The Authorized Biography (London: Allen Lane, 2013).

Njølstad, O., 'The collapse of superpower détente, 1975-1980,' in The Cambridge History of the Cold War: Volume III Endings, ed. M.P. Leffler and O.A. Westad, 135-155 (Cambridge: Cambridge University Press, 2010).

Pach Jr., C., 'Sticking to His Guns: Reagan and National Security,' in The Reagan Presidency: Pragmatic Conservatism and its Legacies, ed. E.W. Brownlee and H.D. Graham, 85-112 (Lawrence: University Press of Kansas, 2003). 
Parr, H., 'The British Decision to Upgrade Polaris, 1970-4,' Contemporary European History 22/2 (2013), 253-274.

Payne, A.J., 'The Belize Triangle: Relations with Britain, Guatemala and the United States,' Journal of Interamerican Studies and World Affairs 32/1 (1990), 119135.

Priest, A., 'In American Hands: Britain, the United States and the Polaris Nuclear Project, 1962-1968,' Contemporary British History 19/3 (2005), 353-376.

Priest, A., Kennedy, Johnson and NATO: Britain, America and dynamics of alliance, 1962-68 (Oxon: Routledge, 2006).

Randall, S. and G. Mount., The Caribbean Basin: an International History (London: Routledge, 1998).

Robb, T., 'Antelope, Poseidon or a Hybrid: The upgrading of the British Strategic Nuclear Deterrent,' Journal of Strategic Studies 33/6 (2010), 797-817.

Robb, T., A strained partnership? US-UK relations in the era of détente, 1969-77. (Manchester: Manchester University Press, 2013).

Sargent, D.J., A Superpower Transformed: The Remaking of Foreign Relations in the 1970s (New York: Oxford University Press, 2015)

Sharp, P., Thatcher's Diplomacy: The Revival of British Foreign Policy (London: MacMillan Press, 1997).

Smith, G., Reagan and Thatcher(London: Bodley Head, 1990).

Spinardi, G., From Polaris to Trident: The Development of US Fleet Ballistic Missile Technology (Cambridge: Cambridge University Press, 1994).

Stewart, G., Bang! A History of Britain in the 1980s (London: Atlantic Books, 2013).

Stoddart, K., 'Creating the "Seamless Robe of Deterrence",' in The Euromissile Crisis and the End of the Cold War, ed. L. Nuti, F. Bozo, M. Rey and B. Rother, 176195 (Washington: Woodrow Wilson Center Press, 2015).

Stoddart, K., 'The British Labour Government and the Development of Chevaline, 1974-79,' Cold War History 10/3 (2010), 287-314.

Stoddart, K., 'The Wilson Government and British Responses to Anti-Ballistic Missiles 1964-1970', Contemporary British History 23/1 (2009), 1-33.

Stoddart, K., Facing Down the Soviet Union: Britain, the USA, NATO and Nuclear Weapons, 1976-1983 (Basingstoke: Palgrave Macmillan, 2014).

Thatcher, M., The Downing Street Years (London: HarperCollins, 1993).

Vinen, R., 'Thatcherism and the Cold War,' in Making Thatcher's Britain, ed. B. Jackson and R. Saunders, 199-217 (Cambridge: Cambridge University Press, 2012). 